\title{
Trypanocidal activity of methanol extracts of the hemolymph of Sarcophaga argyrostoma larva against Trypanosoma evansi infected mice
}

\author{
Doaa S. Farghaly (D) and Al-Shaimaa M. Sadek D \\ Department of Zoology and Entomology, College of Science, Al-Azhar University, P. O. 11765, Cairo 11865, Egypt. \\ Corresponding author: Al-Shaimaa M. Sadek, e-mail: outofarea_2010@yahoo.com \\ Co-author: DSF: doaaFayad2342.el@azhar.edu.eg \\ Received: 16-03-2020, Accepted: 24-06-2020, Published online: 15-08-2020
}

doi: www.doi.org/10.14202/vetworld.2020.1599-1604 How to cite this article: Farghaly DS, Sadek AM (2020) Trypanocidal activity of methanol extracts of the hemolymph of Sarcophaga argyrostoma larva against Trypanosoma evansi infected mice, Veterinary World, 13(8): 1599-1604.

\begin{abstract}
Background and Aim: Many natural products worldwide are used for medicinal purposes. Various insect-isolated compounds were investigated in pursuit of new therapeutic agents. This study aimed to compare the effects of methanol extract of hemolymph of Sarcophaga argyrostoma larvae with diminazene aceturate on some hematological and biochemical indices of mice infected with Trypanosoma evansi.

Materials and Methods: Sixteen albino mice were randomly divided into four groups, of four mice, which received different treatments: In Group 1 (G1), mice were infected intraperitoneally with $1 \times 10^{4} \mathrm{~T}$. evansi and received no treatment (positive control), in Group 2 (G2), infected mice were treated with $0.5 \mathrm{~mL} / \mathrm{kg}$ of diminazene aceturate, in Group 3 (G3), infected mice were treated with $0.5 \mathrm{~mL} / \mathrm{kg}$ methanol extract of the hemolymph of $S$. argyrostoma larvae, and in Group 4 (G4), uninfected mice received $0.5 \mathrm{ml}$ of distilled water (negative control). In G3, treatment was started 3 days before injecting the parasite, while for the other groups, a single dose of treatment was applied when the parasite appeared in the blood.
\end{abstract}

Results: Mice from G3 showed low parasitemia of $29 \times 10^{4} / \mathrm{mm}^{3} 4$ days post-infection until the infection completely disappeared on the $5^{\text {th }}$ day, which was earlier than for other groups. The results showed that the numbers of red blood corpuscles (red blood cells $[\mathrm{RBCs}]$ ) and white blood cells $(\mathrm{WBCs})$ per unit volume were significantly different $(\mathrm{p}<0.05)$ between the four groups. The highest RBC $\left(9.09 \times 10^{3}\right.$ cell $\left./ \mathrm{mm}^{3}\right)$ and WBC $\left(14.30 \times 10^{3} \mathrm{cell} / \mathrm{mm}^{3}\right)$ counts were recorded in $\mathrm{G} 3$, whereas the lowest values of 6.60 and $4.60 \times 10^{3} \mathrm{cell} / \mathrm{mm}^{3}$, respectively, were recorded for $\mathrm{G} 2$. In addition, there were significant differences $(\mathrm{p}<0.05)$ between the different groups for platelet counts per unit volume, with G3 having the most $\left(943 \times 10^{3} \mathrm{cell} / \mathrm{mm}^{3}\right)$ and G2 having the least $\left(357 \times 10^{3} \mathrm{cell} / \mathrm{mm}^{3}\right)$. There was a significant $(\mathrm{p}<0.05)$ difference in the indices of biochemical activities between the extract-treated infected groups and the standard drug-treated group.

Conclusion: This study suggests that the methanol extract of the hemolymph of S. argyrostoma larva exhibits trypanocidal activity, so it may be exploited as a suitable candidate for the development of trypanocidal drugs.

Keywords: diminazene aceturate, hematology, methanol extract, Sarcophaga argyrostoma larva, trypanocidal activity, Trypanosoma evansi.

\section{Introduction}

Animal trypanosomiasis is caused by Trypanosoma brucei, Trypanosoma evansi, Trypanosoma congolense, and Trypanosoma vivax [1] and occurs over $\sim 25$ million $\mathrm{km}^{2}$ in Africa. It limits the growth of the livestock industry in Africa [2] and poses a major obstacle to economic development. Therefore, it is a priority for biomedical and public agencies, the agricultural sector, and the scientific community [3].

Among mammalian trypanosomes, T. evansi is the most ubiquitous parasite [4]. The control of trypanosomosis over the years has broadly included

Copyright: Farghaly and Sadek. Open Access. This article is distributed under the terms of the Creative Commons Attribution 4.0 International License (http://creativecommons.org/licenses/ by/4.0/), which permits unrestricted use, distribution, and reproduction in any medium, provided you give appropriate credit to the original author(s) and the source, provide a link to the Creative Commons license, and indicate if changes were made. The Creative Commons Public Domain Dedication waiver (http:// creativecommons.org/publicdomain/zero/1.0/) applies to the data made available in this article, unless otherwise stated. two strategies, including the use of chemotherapeutic agents and vector control [5]. Chemotherapy for T. evansi in domestic livestock depends on restricted compounds, of which several are closely related chemically. Of these compounds, the most excessively used therapeutic agent is diminazene aceturate. At present, diminazene aceturate (DA), isometamidium, and homidium chloride are used to treat animal trypanosomosis [5]. Although the usage of diminazene is common in most African countries, many research studies have proven that there are many problems related to its use, such as DNA damage, organ damage from the hepatotoxic and nephrotoxic effects of DA residues [6], and indirect effects on the host immune system [7].

Attempts to find new trypanocidal drugs have become more or less static over the past three decades because of a lack of interest by the pharmaceutical industry to invest in research and development of new anti-trypanosomal drugs [8]. 
To date, the fight against this disease relies chiefly on old chemotherapy and chemoprophylaxis, which are expensive and toxic, with severe and even fatal side effects when the blood-brain barrier is crossed [9]. In addition, the appearance of drug-resistant trypanosomes aggravates the problem, which calls for more research into the development of alternative, less toxic, and more efficient drugs [1].

In traditional medicine, insect bodies, eggs, and secretions have been used to cure diseases for more than 2000 years. Recently, modern scientific studies have revealed the therapeutic functions of insect extractions, including their antibacterial, anti-inflammatory, anti-tumor, immune regulating, and blood sugar reducing properties. Numerous compounds extracted from insects have been tested as important resources for the discovery of new drugs [10].

Insects and their products are essential ingredients in the preparation of drugs in folklore medicine [11]. The housefly, Musca domestica, is the most common of all domestic flies, and it accounts for about 91\% of all flies in human habitation. It is one of the major insect that is globally distributed [12]. Extractives from houseflies have been cited for their antioxidant [13], antimalarial [14], antibacterial, immune activation, antiviral, and antitumor properties [15]. As necrophagous flies live in an environment filled with microorganisms, they must possess robust immune cellular and humoral components to counter infection [16]. Antibacterial peptides have been isolated from the hemolymph of flesh fly, Sarcophaga peregrina, larvae [17].

Shittu et al. [14] revealed that the methanol extract of $M$. domestica maggots contains antiplasmodial activity. This finding demonstrated the significance of insects and their products for the development of new drugs for treating malaria and other infectious diseases.

Biochemical parameters are useful markers for assessing tissue damage [18]. Deficiencies in the activities of these markers mirror the level of infection and toxicity of test compounds [19], as it has been established that trypanosomal infection alters biomarker enzymes [1]. Therefore, this study compared the trypanocidal activity of methanol extracts of the hemolymph of Sarcophaga argyrostoma larvae and DA and their effects on some enzymes and hematological parameters in T. evansi infected mice.

\section{Materials and Methods}

\section{Ethical approval}

Animal experiments were conducted according to the requirements of the Institutional Animal Care and Use Committee, National Research Centre Animal Care Unit in Egypt, which is compatible with the guidelines of the International Animal Ethics committee ( $8^{\text {th }}$ Edition 2011) by Institute for Laboratory Animal Research; Division of Earth and Life Studies; National Research Council (Record number: 13799, legacy ID: 8247); and the local laws and regulations.

\section{Study period and location}

The study was conducted from April to June 2019. Sarcophaga argyrostoma larvae were collected and maintained for several generations at the laboratory of the Zoology Department, Faculty of Science, Al-Azhar University and then extraction of hemolymph was conducted in the regional center of fungi and its application in Cairo, Egypt. The experimental part of the study was realized at Faculty of Veterinary, Assiut University, Egypt.

\section{Collection of S. argyrostoma}

Insect colony

$S$. argyrostoma larvae were collected and maintained for several generations at the laboratory of the Zoology Department, at the Faculty of Science, Al-Azhar University, under controlled conditions of $25 \pm 5^{\circ} \mathrm{C}, 60 \pm 10 \%$ relative humidity, and a 12:12 h light:dark photoperiod. Adults were fed on $10 \%$ sucrose solution while maggots were reared on bovine meat [20].

\section{Hemolymph collection}

Hemolymph was collected from each group by cutting off the anterior tip of the larvae using sterile, fine scissors, and placing it in an ice-cold Eppendorf containing a few crystals of phenylthiourea to prevent melanization [21]. The hemolymph was then put through the lyophilization process following LaTorre-Snyder [22]. Then, $20 \mathrm{~g}$ of the powder extract was dissolved in absolute methanol in a closed glass vessel and kept in the shade for $48 \mathrm{~h}$, after which it was filtered through Whatman filter paper. The filtrate was collected in a beaker, exposed to air, and allowed to evaporate for 2 weeks at room temperature $\left(37^{\circ} \mathrm{C}\right)$, then redissolved in dimethyl sulfoxide to yield a final concentration of approximately $10 \mathrm{mg} / \mathrm{ml}$. The work was conducted in the regional center of fungi and its application in Cairo, Egypt.

\section{Experimental animals}

Sixteen male albino mice, Mus domesticus, with an average weight of 30-35 g were obtained from the Veterinary College at Assiut University, Egypt. Animals were examined to check that they were free of parasitic infection to avoid the production of antibodies before the experiments, and they were kept in an animal house under standard laboratory care of $21^{\circ} \mathrm{C}$ and $16 \%$ moisture, with water available ad libitum and a diet containing $20 \%$ protein, $3 \%$ fat, and $22 \%$ fiber. The mice were acclimatized for 7 days before starting the experiment.

\section{Collection of blood samples}

Blood specimens were collected from camels that had been imported from Sudan and were housed in the quarantine area in the Halayeb and Shalateen area $\left(23^{\circ} 7^{\prime} 54^{\prime \prime} \mathrm{N} 35^{\circ} 35^{\prime} 8^{\prime \prime} \mathrm{E}\right)$, which is located on the Northeast African coast of the Red Sea. Twenty $\mathrm{mL}$ of blood was drawn from the jugular vein of camels under complete aseptic conditions. 


\section{Examination of fresh blood for T. evansi}

Fresh blood was examined before the inoculation of trypanosomes in animals. A drop of blood was examined immediately under the low power of a microscope. In some cases (when the parasite was not obvious under the low power), blood was immediately centrifuged for $\sim 15 \mathrm{~min}$ and the deposit was examined for the presence of trypanosomes, which are usually identified by their characteristic movements [23].

\section{Drug usage}

DA (Berenil, Hoechst, Germany) was dissolved, prepared as aliquots following the manufacturer's instructions, and injected intraperitoneally at a concentration of $0.5 \mathrm{~mL} / \mathrm{kg}$ of body weight following MSD animal health instructions, 2020.

\section{Treatment of animals}

Animals were randomly divided into four groups of four mice: The first group (G1) was positive control, which was infected intraperitoneally with $1 \times 10^{4}$ $T$. evansi and received no treatment, the second group (G2) was injected intraperitoneally with $T$. evansi and treated with $0.5 \mathrm{~mL} / \mathrm{kg}$ of DA, the third group (G3) was injected with $T$. evansi parasite and treated with $0.5 \mathrm{~mL} / \mathrm{kg}$ methanol extract, and the fourth group was the negative control, which was uninfected and received $0.5 \mathrm{ml}$ of distilled water. In G3, the treatment was started 3 days before the mice were infected, and the other treatments were given as a single dose when the parasite appeared in the blood.

\section{The daily follow-up}

Daily examination of the blood of laboratory-infected animals was conducted using wet smears and thin and thick films to test for the presence of trypanosomes to determine parasitemia. Blood was obtained from the tail and examined under a microscope at $100 \times$ following the Pizzi-Brener method [24].

\section{Blood collection and preparation}

Mice were anesthetized using cotton wool soaked in chloroform, and their abdominal cavities were opened until the sternum using medical scissors. Blood samples were directly drawn from the heart using a $5 \mathrm{ml}$ sterile syringe into clean, dry centrifuge tubes, which were allowed to stand for $10 \mathrm{~min}$ at room temperature $\left(37^{\circ} \mathrm{C}\right)$, and then centrifuged at $3000 \times \mathrm{g}$ for 15 min using a laboratory centrifuge (SM 800B, Surgifriend Medicals, England). Sera were carefully removed and stored frozen at $-80^{\circ} \mathrm{C}$ until their use for biochemical analyzes. The blood used for hematological analysis was collected into heparinized sample tubes containing ethylenediaminetetraacetic acid to prevent the blood from clotting and taken for analyzes within $24 \mathrm{~h}$ of collection.

\section{Hematological studies}

Hematological parameters, including red blood cells (RBCs), platelet counts, hemoglobin (HB) levels, packed cell volume (PCV), and white blood cells (WBCs), were determined using an automated hematologic analyzer SYSMEX, KX-21 (Japan), as previously described [25].

\section{Biochemical analysis}

Serum samples were analyzed for total protein (TP) using the biuret method, albumin (Al) using bromocresol green, glucose, and bilirubin. In addition, the activity of liver enzymes, alanine aminotransferase (ALAT) or glutamic pyruvic transaminase, aspartate aminotransferase (ASAT) or glutamic oxaloacetic transaminase, acid phosphatase (AcP), and alkaline phosphatase (ALP) was determined. All biochemical parameters were determined using a Technicon RA-2000 random access, automated analyzer. All hematological and biochemical parameters were estimated using commercial kits (Biodiagnostic Co., Dokki, Giza, Egypt), as described in the manufacturer's instructions.

\section{Statistical analysis}

The results were expressed as the mean \pm standard deviation of the mean, and the significant difference between means was evaluated using a one-way analysis of variance followed by a post hoc test for the comparison of significance using the Statistical Package program SPSS version 23.0 (IBM SPSS Statistics, USA). Values of $\mathrm{p}<0.05$ were considered statistically significant.

\section{Results}

\section{Estimation of parasitemia}

Four days post-infection, all animals in the infected groups tested positive for T. evansi. The average prepatent period ranged from 2 to 3 days. Mice from G3 showed low parasitemia $29 \times 10^{4} / \mathrm{mm}^{3} 4$ days post-infection until the infection completely disappeared on the $5^{\text {th }}$ day, which was earlier than the other groups. The course of the parasitemia in the groups is shown in Table-1.

\section{Hematological studies}

Counts of RBCs and WBCs were significantly different $(p<0.05)$ between the four groups (Table-2). The highest counts per unit volume of RBCs

Table-1: Course of parasitemia in mice experimentally infected with $T$. evansi over the 10 days of the experiment.

\begin{tabular}{lccc}
\hline $\begin{array}{l}\text { Days } \\
\text { post } \\
\text { infection }\end{array}$ & $\begin{array}{c}\text { G1 infected } \\
\text { with } \boldsymbol{T} \text {. evansi }\end{array}$ & $\begin{array}{c}\text { G2 infected } \\
\text { and treated } \\
\text { with Berenil }\end{array}$ & $\begin{array}{c}\text { G3 infected } \\
\text { and treated } \\
\text { with methanol } \\
\text { extract }\end{array}$ \\
\hline 4 & $32 \times 10^{4} / \mathrm{mm}^{3}$ & $30 \times 10^{4} / \mathrm{mm}^{3}$ & $29 \times 10^{4} / \mathrm{mm}^{3}$ \\
5 & $58 \times 10^{4} / \mathrm{mm}^{3}$ & $28 \times 10^{4} / \mathrm{mm}^{3}$ & $\mathrm{Nil}$ \\
6 & $122 \times 10^{4} / \mathrm{mm}^{3}$ & $20 \times 10^{4} / \mathrm{mm}^{3}$ & $\mathrm{Nil}$ \\
7 & $157 \times 10^{4} / \mathrm{mm}^{3}$ & $22 \times 10^{4} / \mathrm{mm}^{3}$ & $\mathrm{Nil}$ \\
8 & $260 \times 10^{4} / \mathrm{mm}^{3}$ & $\mathrm{Nil}$ & $\mathrm{Nil}$ \\
9 & $300 \times 10^{4} / \mathrm{mm}^{3}$ & $\mathrm{Nil}$ & $\mathrm{Nil}$ \\
10 & $320 \times 10^{4} / \mathrm{mm}^{3}$ & $\mathrm{Nil}$ & $\mathrm{Nil}$ \\
\hline
\end{tabular}

T. evansi=Trypanosoma evansi 
Table-2: Hematological studies of infected, treated, and control groups.

\begin{tabular}{lccccc}
\hline \multirow{2}{*}{ Parameter } & \multicolumn{4}{c}{ Groups } & \multirow{2}{*}{ 土SEM } \\
\cline { 2 - 5 } & G1 & G2 & G3 & G4 & \\
\hline RBCs & $7.00^{\mathrm{c}}$ & $6.60^{\mathrm{d}}$ & $9.09^{\mathrm{a}}$ & $8.12^{\mathrm{b}}$ & 0.04 \\
$\left(\times 10^{3} \mathrm{cell} / \mathrm{mm}^{3}\right)$ & & & & & \\
$\begin{array}{l}\text { WBCs } \\
\left(\times 10^{3} \mathrm{cell} / \mathrm{mm}^{3}\right)\end{array}$ & $7.80^{\mathrm{b}}$ & $4.60^{\mathrm{c}}$ & $14.30^{\mathrm{a}}$ & $13.80^{\mathrm{a}}$ & 0.26 \\
$\begin{array}{l}\text { Platelets } \\
\left(\times 10^{3} \mathrm{cell} / \mathrm{mm}^{3}\right)\end{array}$ & $561^{\mathrm{c}}$ & $357^{\mathrm{d}}$ & $943^{\mathrm{a}}$ & $783^{\mathrm{b}}$ & 0.58 \\
HB $(\mathrm{g} / \mathrm{dL})$ & $12.50^{\mathrm{c}}$ & $12.30^{\mathrm{d}}$ & $15.40^{\mathrm{a}}$ & $14.80^{\mathrm{a}}$ & 0.06 \\
PCV $(\%)$ & $31.00^{\mathrm{c}}$ & $29.24^{\mathrm{d}}$ & $37.63^{\mathrm{a}}$ & $35.20^{\mathrm{b}}$ & 0.29 \\
\hline
\end{tabular}

RBCs $=$ Red blood corpuscles, WBCs $=$ White blood cells, $\mathrm{HB}=$ Hemoglobin, $\mathrm{PCV}=$ Packed cell volume. Different letters $a, b, c$ within the same row indicate significant differences $p<0.05$

$\left(9.09 \times 10^{3} \mathrm{cell} / \mathrm{mm}^{3}\right)$ and WBCs $\left(14.30 \times 10^{3} \mathrm{cell} / \mathrm{mm}^{3}\right)$ were recorded in G3 followed by G4 (8.12 and $13.80 \times 10^{3} \mathrm{cell} / \mathrm{mm}^{3}$, respectively), whereas $\mathrm{G} 2$ showed the lowest values for RBCs $\left(6.60 \times 10^{3}\right.$ cell $\left./ \mathrm{mm}^{3}\right)$ and WBCs $\left(4.60 \times 10^{3}\right.$ cell $\left./ \mathrm{mm}^{3}\right)$. For platelet counts, there were significant differences $(\mathrm{p}<0.05)$ between the four groups. Mice in G3 had the highest $\left(943 \times 10^{3} \mathrm{cell} / \mathrm{mm}^{3}\right)$ platelet counts followed by mice in G4 $\left(783 \times 10^{3} \mathrm{cell} / \mathrm{mm}^{3}\right)$ then mice in G1 (561), whereas the lowest value was recorded for mice in G2 $\left(357 \times 10^{3}\right.$ cell $\left./ \mathrm{mm}^{3}\right)$. Similarly, the treatment had a significant $(p<0.05)$ effect on HB and PCV concentrations: Mice in $\mathrm{G} 3$ showed the highest $(15.40 \mathrm{~g} / \mathrm{dL}$ and $37.63 \%)$ values followed by G4 (14.80 g/dL and $35.20 \%)$ then G1 (12.50 g/dL and 31.00), while the lowest value was recorded by G2 (12.30 g/dL and 29.24\%) for HB and PCV, respectively (Table-2).

\section{Biochemical studies}

Statistical analysis revealed significant differences in TP concentration due to treatments $(\mathrm{p} \leq 0.05$; Table-3): The highest ( $8.10 \mathrm{mg} / \mathrm{dL}) \mathrm{TP}$ values were for mice in G3 followed by mice in G1 $(7.70 \mathrm{mg} / \mathrm{dL})$ and G4 $(7.60 \mathrm{mg} / \mathrm{dL})$, while the lowest value was recorded for mice in $\mathrm{G} 2(7.00 \mathrm{mg} / \mathrm{dL}$; Table-3). However, mice in G4 had a higher $(\mathrm{p}<0.05)$ value of $\mathrm{Al}$ than other groups, while $\mathrm{G} 3$ had the highest $(\mathrm{p}<0.05)$ globulin concentrations (Table-3), whereas glucose and ALP concentrations were highest $(\mathrm{p}<0.05)$ in $\mathrm{G} 1$, glucose was lowest in G4 and ALP was lowest in G2 (Table-3). However, mice in G2 group had the highest concentration of AcP, which was significantly higher than that for G3 and G4 mice (Table-3).

Values of ALAT (IU/L) and ASAT (IU/L) in the sera of mice were significantly different between treatments: The mice in G1 and G2 had higher $(\mathrm{p}<0.05)$ concentrations of ALAT and ASAT than those in G3 and G4 (Table-3). Finally, mice in G1 and G3 had higher $(\mathrm{p}<0.05)$ concentrations of bilirubin than those in G2 and G4 (Table-3).

\section{Discussion}

Insects and their products constitute essential ingredients for the preparation of drugs in
Table-3: Biochemical studies of infected, treated, and control groups.

\begin{tabular}{|c|c|c|c|c|c|}
\hline \multirow[t]{2}{*}{ Parameter } & \multicolumn{4}{|c|}{ Groups } & \multirow[t]{2}{*}{ ISEM } \\
\hline & G1 & G2 & G3 & G4 & \\
\hline $\begin{array}{l}\text { Total protein } \\
(\mathrm{mg} / \mathrm{dl})\end{array}$ & 7.70 & $\mathrm{~b}$ & $b^{a}$ & $\mathrm{ab}$ & .26 \\
\hline Albumin (mg/dL) & J & J & & . & 0.06 \\
\hline$g / d L)$ & $4.30^{\mathrm{abc}}$ & $3.80^{\mathrm{ab}}$ & & & 0.02 \\
\hline$(\mathrm{mg} / \mathrm{dL})$ & $140^{a}$ & $134^{\mathrm{b}}$ & $122^{c}$ & $120^{d}$ & 0.58 \\
\hline ALP ( & $105^{\mathrm{a}}$ & $14.00^{d}$ & $16.00^{c}$ & $18.03^{b}$ & 0.52 \\
\hline $\mathrm{ACP}(\mathrm{U} / \mathrm{L})$ & $0.90^{\mathrm{ab}}$ & $1.02^{\mathrm{a}}$ & $0.80^{\mathrm{b}}$ & $0.03^{c}$ & 0.04 \\
\hline ALAT (GPT) (U/L & $46.80^{a}$ & $45.20^{a}$ & $35.00^{\mathrm{b}}$ & $18.00^{c}$ & 0.52 \\
\hline ASAT (GOT) (U/L) & $146^{b}$ & $166^{\mathrm{a}}$ & $80.00^{c}$ & $72.30^{d}$ & 0.52 \\
\hline $\begin{array}{l}\text { Bilirubin } \\
\text { (mg/dL) }\end{array}$ & $0.62^{\mathrm{a}}$ & $0.56^{b}$ & $0.62^{a}$ & $0.24^{c}$ & 0.01 \\
\hline
\end{tabular}

$\mathrm{ALP}=$ Alkaline phosphatase, $\mathrm{ACP}=$ Acid phosphatase, ALAT $(G P T)=$ Alanine aminotransferase (glutamic pyruvic transaminase), ASAT (GOT)=Aspartate aminotransferase (glutamic oxaloacetic transaminase). Different letters a, $b, c$ within the same row indicate significant differences $\mathrm{p}<0.05$

folklore medicine [11]. Assessments of biochemical parameters are a useful marker for assessing tissue damage [18]. Deficiencies in the activities of these markers indicate levels of infection and toxicity of test compounds [19], and trypanosomal infection alters biomarker enzymes [1].

This study demonstrates that $10 \mathrm{mg} / \mathrm{ml}$ concentrations of methanol extract of hemolymph of S. argyrostoma larva significantly inhibited $T$. evansi organisms in vivo. Similar results were recorded by Shittu et al. [26] using methanol extract of M. domestica larva. The observed inhibition may be an indication of the possible utility of the methanol extract of hemolymph of larva as an anti-trypanosomal agent.

Animal trypanosomiasis is characterized by hematological changes, which radically alter the pathogenesis of the disease in infected animals $[1,27,28]$. The lower concentrations of RBCs, HB, and PCV in the untreated, infected group are indications of anemia as recorded by Padmaja [29] and Eyob and Matios [30]. Decreased values of the same parameters in untreated, infected mice and infected mice treated with Berenil might be due to increased susceptibility of RBC membranes to oxidative damage [31], or as suggested by Kramer [32], anemia could be due to the depletion of erythrocytes, which might be a result of chronic liver inflammation. The increase in $\mathrm{RBC}, \mathrm{HB}$, and PCV concentrations in the infected mice treated with methanol extract suggests that the extract reduces the anemic effect of $T$. evansi in mice and helps improve hematological parameters by decreasing oxidative stress markers, as proposed by Raish et al. [33]. This study also showed that infection with $T$. evansi induced leukopenia and this was enhanced by treatment with methanol extract. Leukocytosis, which was recorded in our study, is a good indicator of enhancement and strengthening of the immune system by increasing the mean production of WBCs [34] and increasing mononuclear phagocytic system activity [35]. 
The efficiency of some organs was investigated using biochemical markers. We found that the mean values of serum $\mathrm{TP}, \mathrm{Al}$, and globulin were significantly lower in the positive control. In addition, values for these parameters were lower for the infected mice treated with Berenil than for those treated with methanol extract. The decrease in total serum protein level observed in our study is in agreement with the results of Abo-Aziza et al. [28], who reported a decrease in TP in camels infected with $T$. evansi and with Sivajothi et al. [27] who reported similar results for infected rabbits. Protein levels usually drop in trypanosome infections as a result of hepatic degeneration, damage accompanying hypoxia [36], and parasite antigens [37]. The elevations in proteins levels after treatment with methanol extract are usually due to increases in globulin levels. This is as a result of improving the immune response of the animal to T. evansi infection [38].

Our biochemical results revealed a marked increase in glucose in the experimentally infected animals (G1 and G2) that may be due to host organ damage at a cellular level due to toxic releases from parasites and immune complexes [36,39]. This is in accordance with Garba and Mayaki [40], who recorded high levels of glucose in donkeys infected with $T$. evansi. There was an improvement in blood glucose level in the infected mice that were treated with methanol extract (G3). This finding could be due to decreases in parasitemia levels, which lead to decreasing glucose demand by parasites [41].

As far as the activity of enzymes is concerned, ALP, AcP, ALAT, and ASAT activities showed a decrease in the group treated with methanol extract compared with the positive control group. In addition, there was a marked increase in enzymatic hepatic activity, such as ALP and AcP in untreated mice (G1) when compared with those treated with the extract (G3). Our findings are in accordance with those of Yakubu et al. [19]. The elevation in ALP and AcP activities in the untreated group (G1) could be attributed to infection gradually affecting enzyme levels by increasing the activation of the enzyme molecule at the site and releasing membrane components, such as alkaline and AcP, into the extracellular fluids.

Several studies have also previously reported significant increases in ALAT and ASAT activities in Trypanosoma sp. infected animals [26-28]. These studies explained that liver infection with Trypanosoma led to hepatocyte destruction and enzyme release and indicates a cellular response. However, mice treated with methanol extract of $S$. argyrostoma hemolymph showed improved enzymatic hepatic activities by significantly decreasing the serum activities of the elevated ALP, AcP, ASAT, and ALAT.

Increased quantities of total bilirubin may also indicate the increased breakdown of HB due to Trypanosoma spp. [42]. This result is in agreement with Gow et al. [43] who observed that dogs naturally infected with $T$. congolense had elevated levels of bilirubin and Sivajothi et al. [27] who recorded elevated bilirubin levels in rabbits infected with $T$. evansi.

\section{Conclusion}

Our results prove that the methanol extract of the hemolymph of S. argyrostoma larva has trypanocidal activities. Therefore, further investigations should be conducted on insect products as a natural treatment that could be exploited as a new generation of trypanocidal agents.

\section{Authors' Contributions}

DSF collected the larvae of insects. AMS carried out biochemical and hematological tests. Both authors followed up the experiment, wrote and revised the manuscript, and approved the final manuscript.

\section{Acknowledgments}

The authors are grateful to the technicians of the Regional Center of Fungi and its application in Cairo and Faculty of Veterinary, Assiut University for their help in getting the work done. This study did not receive any external funding.

\section{Competing Interests}

The authors declare that they have no competing interests.

\section{Publisher's Note}

Veterinary World remains neutral with regard to jurisdictional claims in published institutional affiliation.

\section{References}

1. Bashir, L., Shittu, O.K., Sani, S., Busari, M.B. and Adeniyi, K.A. (2015) African natural products with potential anti-trypanosomal properties: A review. Int. J. Biochem. Res. Rev., 7(2): 45-79.

2. World Health Organization. (2017) African Trypanosomiasis or Sleeping Sickness. Fact Sheet, No. 259. World Health Organization, Geneva, Switzerland.

3. Gilbert, J.A., Medlock, J., Townsend, J.P., Aksoy, S., Mbah, M.N. and Galvani, A.P. (2016) Determinants of human African trypanosomiasis elimination via paratransgenesis. PLoS Negl. Trop. Dis., 10(3): 1-16.

4. Birhanu, H., Gebrehiwot, T., Goddeeris, B.M., Büscher, P. and Van Reet, N. (2016) New Trypanosoma evansi Type B isolates from Ethiopian dromedary camels. PLoS Neglec. Trop. Dis., 10(4): 1-22.

5. Adeyemi, O.S. and Sulaiman, F.A. (2015) Evaluation of metal nanoparticles for drug delivery systems. J. Biomed. Res., 29(2): 145-149.

6. Baldissera, M.D., Sagrillo, M.R., Grando, T.H., Rosa, L.D., de Sá, M.F., da Luz, S.C., Silveira, S.O., Nascimento, K., Peres, D.S., Copetti, P.M. and da Silva, A.S. (2017) Cytotoxic and genotoxic effects of the trypanocidal drug diminazeneaceturate. Comparative Clin. Pathol., 26(1): 219-227.

7. Giordani, F., Morrison, L.J., Rowan, T.G., De Koning, H.P. and Barrett, M.P. (2016) The animal trypanosomiases and their chemotherapy: A review. Parasitology, 143(14): 1862-1889.

8. Kuriakose, S. and Uzonna, J.E. (2014) Diminazeneaceturate (Berenil), a new use for an old compound? Int. Immunopharmacol., 21(2): 342-345. 
9. Haffiz, J.M., Norhayati, I., Getha, K., Azah, M.A.N., Mohdlham, A., Sahira, H.L., Jahn, M.S.R. and Syamil, A.M. (2013) Chemical composition and in vitro anti-trypanosomal activity of fractions of essential oil from Cymbopogon nardus L. Trop. Biomed., 30(1): 9-14.

10. Feng, Y., Zhao, M.Z., Chen, Z. and Sun, L. (2009) Research and utilization of medicinal insects in China. Entomol. Res., 39(5): 313-316.

11. Fred-Jaiyesimi, A.A. and Awobajo, O. (2011) Biochemical and histopathological investigation of the effect of Achachatina marginata haemolymph in normal rats. Int. J. Appl. Biol. Pharm. Technol., 2(4): 30-33.

12. Marek, G., Malgorzata, D., Wojciech, K., Mieczyslawa, I., Bogus, W.W., Emilia, W., Monika, P., Elzbieta, P. and Piotr, S. (2012) The antimicrobial activities of the alcohol from Musca domestica. J. Exp. Biol. Adv., 215(Pt 19): 3419-3428.

13. Shittu, O.K., Lawal, B. and Oluyomi, O.I. (2014) Effects of methanol extract of Musca domestica larvae on antioxidants enzymes in T. Brucei infected rats. Niger. J. Biochem. Mol. Biol., 29(2): 1-10.

14. Shittu, O., Olayemi, I., Omalu, I. and Adeniyi, A. (2013) Anti-plasmodial properties of methanolic extract of Musca domestica maggot on P. Berghei infected mice. Int. J. Biol. Pharm. Appl. Sci., 2(5): 1064-1070.

15. An, C., Li, D. and Du, R. (2004) Analysis of antibacterial relative proteins and peptides in housefly larvae. J. Hyg. Res., 33(1): 86-88.

16. Hall, M., Wall, R.L. and Steves, J.R. (2016) Traumatic myiasis: A neglected disease in a changing world. Аnnu. Rev. Entomol., 61(17:42): 159-176.

17. Okada, M. and Shunji, N. (1983) Purification and characterization of an antibacterial protein from haemolymph of Sarcophaga peregrina (flesh-fly) larvae. Biochem. J., 211(3): 727-734.

18. Lawal, B., Shittu, O.K., Inje, O.F., Berinyuy, E.B. and Muhammed, H. (2016) Potential antioxidants and hepatoprotectives from African natural products: A review. Clin. Phytosci., 2(1): 23.

19. Yakubu, M.T, Adesokan, A.A. and Akanji, M.A. (2006) Biochemical change in the liver kidney and serum of rat following chronic administration of cimetidine. Afr. J. Biomed. Res., 9(3): 213-218.

20. Bai, C. and Degheele, D. (1988) Characterization of the gut juice and haemolymp proteins of Mamestra brassicae L., Pieris brassicae L. and Spodoptera littoralis (Boisd) larvae and susceptibility to Bacillus thuringiensis var. thuringiensis crystal toxins. Mededelingen van de Faculteit landbouwwetenschappen. Rijksuniversiteit Gent., 53(1): 255-259.

21. Cytorynska, M., Mak, P., Zdybicka-Barabas, P.A., Suder, P. and Jakubowicz, T. (2007) Purification and characterizatoin of eight peptides from Galleria mellonella immune hemolymph. Peptides, 28(3): 533-546.

22. LaTorre-Snyder, M. (2017) Lyophilization: The basics. An overview of the lyophilization process as well as the advantages and disadvantages. Pharm. Process, 32(1): 1-2.

23. Soulsby, E.J.L. (1982) Helminths Arthropods and Protozoa of Domesticated Animals. Vol. 7. EWP, (Baillière Tindall, London) p532-534.

24. Brener, Z. (1962) Therapeutic activity and criterion of cure on mice experimentally infected with Trypanosoma cruzi. Rev. Inst. Med. Trop. Sao Paulo, 4(6): 389-396.

25. Dacie, J.V. and Lewis, S.M. (1991) Practical Haematology. Vol. 7. Churchill Livingstone, Edinburgh. p521-534.

26. Shittu, O.K., Lawal, B., Adeniyi, A.K., Kilani, L.T. and Saka, R.B. (2017) Effect of methanol extract of Musca domestica larva on some enzymes and haematological parameters in Trypanosoma brucei brucei infected rats. Niger. J. Basic Appl. Sci., 25(2): 66-74.

27. Sivajothi, S., Rayulu, V.C. and Reddy, B.S. (2015) Haematological and biochemical changes in experimental Trypanosoma evansi infection in rabbits. J. Parasit. Dis., 39(2): 216-220.

28. Abo-Aziza, F.A., Ashry, H.M. and Nassar, S.A. (2017) Haematological and biochemical alterations in subclinically affected dromedary camels with Trypanosoma evansi during breeding season in Egypt. J. Chem. Pharm. Sci., 10(3): 1326-1334.

29. Padmaja, K. (2012) Haemato-biochemical studies and therapy of trypanosomiasis in camels. Vet. World, 5(6): 356-58.

30. Eyob, E. and Matios, L. (2013) Review on camel trypanosomosis (surra) due to Trypanosoma evansi: Epidemiology and host response. J. Vet. Med. Anim. Health, 5(12): 334-343.

31. Sivajothi, S., Rayulu, V.C., Sujatha, K. and Reddy, B.S. (2015) Study of histopathological changes in experimental Trypanosoma evansi infected rats. Proc. Zool. Soc., 68(2): $112-115$.

32. Kramer, J.W. (2000) Normal hematology of cattle, sheep and goats. Schalms Vet. Hematol., 5:1075-1084.

33. Raish, M., Ahmad, A., Alkharfy, K.M., Ahamad, S.R., Mohsin, K., Al-Jenoobi, F.I., Al-Mohizea, A.M. and Ansari, M.A. (2016) Hepatoprotective activity of Lepidium sativum seeds against D-galactosamine/lipopolysaccharide induced hepatotoxicity in animal model. BMC Complement. Altern. Med., 16(1): 501.

34. Al-Otaibi, M.S., Al-Quraishy, S., Al-Malki, E.S. and AbdelBaki, A.A.S. (2019) Therapeutic potential of the methanolic extract of Lepidium sativum seeds on mice infected with Trypanosoma evansi. Saudi J. Biol. Sci., 26(7): 1473-1477.

35. Ahmadi-Hamedani, M, Khosro, G. and Mohammad, M.D. (2014) Hematological and serum biochemical aspects associated with a camel (Camelus dromedarius) naturally infected by Trypanosoma evansi with severe parasitemia in Semnan, Iran. Asian. Pac. J. Trop. Biomed., 4(9): 743-745.

36. Enwezor, F.N.C. and Sackey, A.K.B. (2005) Camel trypanosomosis a review. Vet. Arhiv, 75(5): 439-452.

37. Azza, M.K. (2008) Some biochemical, hematological and clinical studies of selected ruminal and blood constituents in camels affected by various diseases. Res. J. Vet. Sci., 1(1): 16-27.

38. Allam, L., Ogwu, D., Agbede, R.I. and Sackey, A.K. (2011) Hematological and serum biochemical changes in gilts experimentally infected with Trypanosoma brucei. Vet. Arhiv, 81(5): 597-609.

39. Singh, B.M., Singla, L.D., Kumar, H., Vasudev, A., Gupta, K. and Juyal, P.D. (2012) Pathological studies on experimental Trypanosoma evansi infection in Swiss albino mice. J. Parasit. Dis., 36(2): 260-264.

40. Garba, U.M. and Mayaki A.M (2018) Fluctuations in blood glucose level of donkeys infected with Trypanosoma evansi. ARC J. Anim. Vet. Sci., 4(1): 14-21.

41. Garba, U.M., Sackey, A.K.B., Lawal, A.I. and Esievo, K.A.N. (2016) Dynamics of parasitaemia in Trypanosoma evansi infection in donkeys and the efficacies of buparvaquone and isometamidium chloride treatments. Anim. Vet. Sci., 4(3): 32-38.

42. Takeet, M.I. and Fagbemi, B.O. (2009) Haematological, pathological and plasma biochemical changes in rabbits experimentally infected with Trypanosoma congolense. Sci. World J., 4(2): 29-36.

43. Gow, A.G., Simpson, J.W. and Picozzi, K. (2007) First report of canine African trypanosomosis in the UK. J. Small Anim. Pract., 48(11): 658-661. 